Vol. 4, No. 1, 2021

O. Ya. Smirnova, Yo. Yo.Yatchyshyn, S. V. Kolobych, I. P. Poliuzhyn

Lviv Polytechnic National University, Department of Physical, Analytical and General Chemistry

\title{
NORMAL PHASE THIN LAYER CHROMATOGRAPHY FOR AROMATIC DERIVATIVES OF 3-CHLORO-1,4-NAPHTOCHINONE
}

https://doi.org/ 10.23939/ctas2021.01.033

The chromatographic characteristics were investigated for eight aromatic derivatives of 3chloro-1,4-naphthoquinone under conditions of normal-phase thin-layer chromatography for benzene-based binary mobile phase and such polar solvents as chloroform, acetone, acetonitrile, methanol and propan-2-ol. The slope of linear retention dependencies for the investigated compounds on the concentration of the polar component in the mobile phase satisfactorily correlates with the area occupied by the adsorbed analyte molecule in the stationary phase. The intercept in the Soczewinski equation depends on the polar component of the mobile phase.

Key words: thin-layer chromatography; naphthoquinone-1,4; aromatic derivatives; composition of the eluent; Soczewinski equation.

\section{Introduction}

Natural and synthetic 1,4-naphthoquinone derivatives are used as fungicides and natural dyes [1]. Many synthetic amino and sulfur-containing derivatives of 1,4-naphthoquinone have been studied as antibacterial and antifungal agents, antioxidants, antitumor and antiviral agents [2-5]. Modification of 2,3-dichloro-1,4-naphthoquinone by amine-containing compounds by the nucleophilic substitution reaction of one of the chlorine atoms on the R-amine fragment has been known for a long time and is often used now [6]. Synthesis and study of the biological activity of 1,4-naphthoquinone derivatives continue [7-11].

Although many studies, such as $[2,4,6,7$, 12], concerning the synthesis of 3-chloro-1,4naphthoquinone derivatives, reported that thin layer chromatography (TLC) was used to verify the completion of the reaction, however, no conditions are given for TLC and separation results. In [13], which is one of the first studies of TLC derivatives of 1,4-naphthoquinone, the $R_{f}$ values relative retantion for 15 quinoid compounds using two mobile phases (MP) - chloroform and chloroform-ethyl acetate acetic acid in volume relation 10:10:1. It was established [13] that the $R_{f}$ values decrease significantly when amino or hydroxyl groups appear in the structure of the substance. For example, when chloroform is used as MP, the value of $R_{f}$ for 3-chloro-1,4-naphthoquinone derivatives is reduced from 0.73 for the 2-chloro to 0.18 for the 2-amino derivative. In [14-16], the chromatographic behavior under conditions of normal phase TLC (NP TLC) of three groups of 1,4-naphthoquinone derivatives with different substituents was investigated and it was shown that there are relationships between retention parameters and sorption area (As) of these compounds, which is calculated according to the monograph [17], and the effect of the concentration of the reinforcing component in the MP is well described by the Soczewinski equation [18] for binary MP based on benzene and five polar components. In [10], the $R_{f}$ values, which are systematized by the structure of the substituent in table 1, were studied for amino derivatives of 1,4naphthoquinone under NP TLC with silica gel and three and four-component MP (petroleum ether $\mathrm{PE}$; chloroform - $\mathrm{CHCl}_{3}$; ethyl acetate - EA; methanol $-\mathrm{MeOH}$ ). According to Table 1, it is difficult to establish certain general relationships between the content of compounds and their structure, because the data are obtained from MP of different composition. Even for compounds with 1,2 and 3 , which are homologues with a 
consistent difference per $\mathrm{CH}_{2}$ group, and provided that MPs of the same composition are used, there is no regularity in the $R_{f}$ values equal to 0.78 ; 0.91 and 0.87 , respectively. Theoretically, for normal-phase chromatography (NPC) in the case of such a homologous series, an increase in $R_{f}$ should be observed with increasing number of $\mathrm{CH}_{2}$ groups, but the As value increases for analyte molecules. When considering the MP of the same composition in table 1 , we can distinguish two sequences of two compounds no. $1\left(R_{f}=0.78\right)$ and no. $2\left(R_{f}=0.91\right)$ and no. $9\left(R_{f}=\right.$ $0.37)$ and no. $10\left(R_{f}=0.52\right)$, for which with increasing number of $\mathrm{CH}_{2}$ groups there is an increase in $R_{f}$, so in the NPC conditions according to [10] sorption decreases.

Table 1

$R_{f}$ values for amino derivatives of 1,4-naphthoquinone according to [10]

\begin{tabular}{|c|c|l|c|c|c|c|c|}
\hline \multirow{2}{*}{ No. } & \multirow{2}{*}{$\begin{array}{c}\text { No. } \\
\text { According } \\
\text { to [14] }\end{array}$} & & \multicolumn{1}{c|}{ Substitute } & \multicolumn{3}{|c|}{ Composition of MP, \% vol. } \\
\cline { 5 - 8 } & 1 & $-\mathrm{NH}-\mathrm{CH}_{2}-\mathrm{CH}_{3}$ & & $\mathrm{PE}$ & $\mathrm{CHCl}_{3}$ & EA & $\mathrm{MeOH}$ \\
\hline 1 & 2 & $-\mathrm{NH}-\mathrm{CH}_{2}-\mathrm{CH}_{2}-\mathrm{CH}_{3}$ & 0.78 & 26.7 & 66.6 & 6.7 & 0 \\
\hline 2 & 4 & $-\mathrm{NH}-\mathrm{CH}_{2}-\mathrm{CH}_{2}-\mathrm{CH}_{2}-\mathrm{CH}_{3}$ & 0.91 & 26.7 & 66.6 & 6.7 & 0 \\
\hline 3 & 3 & $-\mathrm{NH}-\mathrm{CH}\left(\mathrm{CH}_{3}\right)-\mathrm{CH}_{3}$ & 0.87 & 26.7 & 66.6 & 6.7 & 0 \\
\hline 4 & 5 & $-\mathrm{NH}-\mathrm{CH}\left(\mathrm{CH}_{3}\right)-\mathrm{CH}_{2}-\mathrm{CH}$ & 0.89 & 26.7 & 66.6 & 6.7 & 0 \\
\hline 5 & 9 & $-\mathrm{NH}-\mathrm{CH}_{3}\left(\mathrm{CH}_{3}\right)-\mathrm{CH}_{2}-\mathrm{CH}\left(\mathrm{CH}_{3}\right)-\mathrm{CH}_{3}$ & 0.96 & 33.3 & 50.0 & 16.7 & 0 \\
\hline 6 & 10 & $-\mathrm{NH}-\mathrm{CH}_{2}-\mathrm{CH}_{2}-\mathrm{C}_{6} \mathrm{H}_{4}-\mathrm{Cl}$ & 0.91 & 28.6 & 57.1 & 14.3 & 0 \\
\hline 7 & 11 & $-\mathrm{N}=\left(\mathrm{CH}_{2}-\mathrm{CH}_{2}\right)_{2}=\mathrm{N}-\mathrm{CH}$ & 0.46 & 34.8 & 4.3 & 60.9 & 0 \\
\hline 8 & 6 & $-\mathrm{NH}-\mathrm{CH}_{2}-\mathrm{CH}_{2}-\mathrm{CH}_{2}-\mathrm{N}=\left(\mathrm{CH}_{3}\right)_{2}$ & 0.37 & 20.0 & 50.0 & 10.0 & 20.0 \\
\hline 9 & 7 & $-\mathrm{NH}-\mathrm{CH}_{2}-\mathrm{CH}_{2}-\mathrm{CH}_{2}-\mathrm{N}=\left(\mathrm{C}_{2} \mathrm{H}_{5}\right)_{2}$ & 0.52 & 20.0 & 50.0 & 10.0 & 20.0 \\
\hline 10 & 8 & $-\mathrm{NH}-\mathrm{CH}_{2}-\mathrm{CH}_{2}-\mathrm{CH}_{2}-\mathrm{N}=\left(\mathrm{C}_{4} \mathrm{H}_{9}\right)_{2}$ & 0.76 & 22.2 & 55.6 & 11.1 & 11.1 \\
\hline 11 & & & & & & \\
\hline
\end{tabular}

Often in articles TLC conditions for 1,4naphthoquinone derivatives are not described, or for analytes used MP with the same components, but in different ratios and an example of such an approach to TLC can be [11], which describes the results of synthesis and study of antimicrobial properties and the ability to inhibit the activity of the catalase enzyme of many N-, S-, O- substituted derivatives of 1,4-naphtho- and bezoquinone. The aim of the researchers [11] was to select such a ratio between $\mathrm{CHCl}_{3}$ and PE that $R_{f}$ were in the range of $0.4-0.6$ and probably the reaction products were separated from the starting materials.

The article [3] can be an example of studies where TLC with chloroform as a one-component MP was used to observe the synthesis of 1,4-naphthoquinone derivatives and for the nine synthesized compounds $R_{f}$ was in the range of $0.32-0.52$. It is necessary to note that systematic studies of the chromatographic content of 1,4-naphthoquinone derivative under NP TLC are limited. As the synthesis and intensive studies of the bioactivity of the new 1,4-naphthoquinone derivatives continue, it is important to obtain relationships between the structure of these analytes and their retention to predict the desired MP composition using the probable structure of the synthesized compounds. This work is a continuation of a series of works [14-16] on the systematic study of the chromatographic behavior of 1,4-naphthoquinone derivatives under NF TLC.

Purpose: to investigate the chromatographic separation of eight aromatic derivatives of 3-chloro 1,4-naphthoquinone using NP TLC, as well as to establish the relationship between the retention and structure of these compounds.

\section{Materials and methods of research}

Table 2 shows the structures of the studied aromatic derivatives of 3-chloro-1,4-naphthoquinone I-VIII, which were synthesized at the Department of Technology of Biologically Active Compounds, Pharmacy and Biotechnology of the Lviv Polytechnic National University using as the initial compound 2,3-dichloro-1,4-naphthoquinone according to the general method number 1 from [3] and provided for 
TLC studies. Table 2 shows the relative area of $A_{S}$ occupied by the adsorbed analyte molecule on the surface of the stationary phase (SP). The relative area of $A_{S}$ is calculated according to [17].

Table 2

Structures of aromatic derivatives of 3-chloro-1,4naphthoquinone and the area of $A_{S}$

\begin{tabular}{|c|c|}
\hline $\begin{array}{c}\text { Substance } \\
\text { number } \\
\text { and } \mathbf{A}_{\mathbf{S}}\end{array}$ & The substance structure \\
\hline (I) & \\
\hline$A_{S}=39.5$ & \\
\hline (II) & \\
\hline $\mathrm{A}_{\mathrm{S}}=39.9$ & \\
\hline (III) & \\
\hline $\mathrm{A}_{\mathrm{S}}=40.2$ & \\
\hline$(\mathbf{I V})$ & \\
\hline$A_{S}=40.3$ & \\
\hline$(\mathbf{V})$ & \\
\hline $\mathrm{A}_{\mathrm{S}}=44.1$ & \\
\hline (VI) & \\
\hline $\mathrm{A}_{\mathrm{S}}=47.1$ & \\
\hline (VII) & \\
\hline $\mathrm{A}_{\mathrm{S}}=47.8$ & \\
\hline (VIII) & \\
\hline$A_{S}=55.5$ & \\
\hline
\end{tabular}

The conditions for chromatographic experiments were the same as in our previous works [14-16], in particular TLC was performed using plates Silufol (manufacturer Kavalier) with broad-pore silica gel Silpearl (according to the Pitra classification). The concentration of solutions of analytes in dimethyl sulfoxide (DMSO) was $2-5 \mathrm{mg} / \mathrm{ml}$, and the volume of solution applied to the starting line was $1 \mu \mathrm{l}$. Chromatograms were obtained by moving the solvent from the bottom to up. Chromatograms after air drying were scanned using a flatbed scanner.

Densitan software [19] was used to process digital images in bitmap format. Scanning was performed with a resolution of $600 \mathrm{dpi}$. The distance from the starting line $(L, \mathrm{~mm})$ was calculated by the formula $L=(N-1) \cdot \Delta L$, where $N$ is the number of measuring points using the Densitan program; $\Delta L=42 \mu \mathrm{m}$ - the distance between two measurement points according to the scan resolution.

For TLC, the basis of binary MPs was benzene, and the elution capacity of MPs was enhanced using components such as chloroform, acetone, acetonitrile, propan-2-ol and methanol at concentrations ranging from 2.5 to $10 \%$ vol. The MP components used in this paper were selected according to the classification proposed by Snyder [18] p. 34. The components of the polarity indices of the MP components are given in Table 3. When choosing solvents for MP in TLC, the literature data concerning the separation of substances with a quinoid structural fragment by the NP TLC method were also taken into account.

Table 3

Increments of polarity indices for MP components based on Snyder system [20, 21]

\begin{tabular}{|l|c|c|c|}
\hline \multicolumn{1}{|c|}{ Solvents } & $\mathrm{X}_{\mathrm{E}}$ & $\mathrm{X}_{\mathrm{D}}$ & $\mathrm{X}_{\mathrm{N}}$ \\
\hline Chloroform & 0.28 & 0.39 & 0.33 \\
\hline Acetone & 0.36 & 0.24 & 0.40 \\
\hline Acetonitrile & 0.33 & 0.26 & 0.41 \\
\hline Methanol & 0.51 & 0.19 & 0.30 \\
\hline Propan-2-ol & 0.54 & 0.20 & 0.26 \\
\hline Benzene & 0.29 & 0.28 & 0.43 \\
\hline
\end{tabular}

To ensure reproducible experimental conditions and obtain reliable retention characteristics, the following TLC parameters kept constant: plate size, starting line distance from bottom $1.0 \mathrm{~cm}$, amount of analyte applied to starting line, solvent volume 
in the chamber, eluent vapor equilibration time, chromatography temperature was room temperature in the range of $18-20{ }^{\circ} \mathrm{C}$. Five chromatograms were obtained for each "analyte-MP" combination of a certain composition, and averaged $R_{f}$ values were used for further generalizations. The standard deviation for determining the $R_{f}$ value was 0.015 .

According to the relative retention of $R_{f}$, which in TLC is calculated by formula (1) as the ratio of the retention distance of the analyte $(L)$ to the distance traveled by the front MP $\left(L_{0}=120 \mathrm{~mm}\right)$, the parameter $R_{M}$ was calculated by formula (2).

$$
\begin{gathered}
\mathrm{R}_{\mathrm{f}}=\frac{\mathrm{L}}{\mathrm{L}_{0}} \\
\mathrm{R}_{\mathrm{M}}=\lg \left(\frac{1}{\mathrm{R}_{\mathrm{f}}}-1\right)
\end{gathered}
$$

Generalization of TLC results was performed according to equation (3), which was proposed by Soczewinski [18] and is based on the concept of competition between MP solvent molecules with analyte molecules for active centers on the surface of the SP adsorbent:

$$
\mathrm{R}_{\mathrm{M}}=\mathrm{A}-\mathrm{B} \cdot \lg \left(\mathrm{N}_{\mathrm{B}}\right)
$$

where $N_{B}$ is the molar fraction of the polar component in the binary mixture of MP; A and B are constants, the values of which depend on the properties of the analyte and the composition of the MP.

For eight aromatic amino derivatives of 3-chloro 1,4-naphthoquinone, the relative area $\left(A_{S}\right)$ occupied by one molecule of compounds I-VIII adsorbed on the SP surface was calculated. In [19], a step-by-step calculation scheme for the basic structural fragment of 2-amino-3-chloro-1,4-naphthoquinone of $A_{S}$ area according to [17] is given. The unit of measurement of the calculated relative area of $\mathrm{A}_{\mathrm{S}}$ corresponds to $0.085 \mathrm{~nm}^{2}$, for example for one methylene group in n-alcohols $A_{S}\left(\mathrm{CH}_{2}\right)=0.9$ or $0.0765 \mathrm{~nm}^{2}$, and for the benzene ring is taken $A_{S}=6$ or $0.510 \mathrm{~nm}^{2}$. Next, by replacing in 2-amino-3chloro-1,4-naphthoquinone one hydrogen atom of the amino group on the corresponding structural fragment $\mathrm{A}_{\mathrm{S}}$ values were obtained for derivatives of 3-chloro1,4-naphthoquinone, the values of which are given in Table 2. Correlation equations were obtained using a spreadsheet MS EXCEL.

\section{Results and discussion}

Table 4 presents the results of relative retention $R_{f}$, the values of which depending on the MP composition for compounds I-VIII is in the range from 0.15 to 0.66 . With the increase of the polar component content in the MP, the $R_{f}$ value naturally increases (Table 4). For compounds I and VII, in the structure of which is no carboxyl group, and for which were obtained, respectively, the minimum and maximum calculated values of $A_{S}$, in Fig. 1 shows examples of the dependences of $R_{f}$ on the volume (\%) and molar fraction of the polar component in the MP. The volume fraction (\%) was calculated from the experimental volumes of benzene and the polar component, allowing the additivity of these values for MP, and the transition from volume (\%) to molar fraction was carried out according to a known dependence that takes into account densities and molar masses of the mixture components. As can be seen from Fig. 1 there is a significant difference between the representation of data in different coordinates of the abscissa axis, which is explained in detail in [15]. When considering Fig. 1 and the data of Table 4 for the use of volume fraction (\%) as the coordinates of the abscissa axis, for all compounds there is an increase in the value of $R_{f}$ when replacing the polar component of MP in the following series: acetonitrile - chloroform - acetone - propane-2-olmethanol, which was also obtained in [14]. This indicates a significant contribution to the adsorption and desorption processes from the 1,4-naphthoquinone fragment, which is common to the sets of compounds studied in [14-16] and in this work. This influence series of the MF polar component nature undergoes significant changes in the transition to the molar fraction as the abscissa axis coordinates, and an increase in $R_{f}$ is observed in the following series: acetonitrile-methanol-chloroform-acetone-propan-2ol, as indicated in [15]. To compare the effect of polar groups in the structure of matter on retention under normal phase TLC for compounds IV, V, VI and VIII according to the Table 4, we consider the dependences of the parameter $R_{f}$ on the volume (\%) fraction of the polar component in MP. The increase in the polarity of the functional groups in the range from methyl to carboxyl groups $-\mathrm{CH}_{3},-\mathrm{O}-\mathrm{CH}_{3},-\mathrm{O}$ $\mathrm{H},-\mathrm{CO}-\mathrm{OH}$ naturally leads to an increase in sorption on the polar stationary phase, which is reflected in the increase in the relative area $\left(A_{S}\right)$, which 
is occupied by one molecule adsorbed on the SF surface.

The change in the difference $\Delta R_{f}$ between neighbors in retention polar components at the same their volume $(\%)$ fraction in the MP has certain patterns. In Fig. 2 shows the values of $\Delta R_{f}$ of the studied substances I-VIII with the use of MP with different polar components at a content of $2.5 \%$ vol. for such pairs: "chloroform-acetonitrile", "methanol - propan-2-ol", "acetone - chloroform", "propan-2-ol-acetone". With the increase in the relative area $\left(A_{S}\right)$, this difference $\Delta R_{f}$ decreases from 0.063 to 0.004 at the replacing of chloroform by acetonitrile in the MP, and conversely, this difference $\Delta \mathrm{R}_{\mathrm{f}}$ increases from almost zero (0.002) to 0.061 at the replacing of propan-2-ol by methanol in the MP. These ratios don`t show any regular changes in the difference $\Delta R_{f}$ with increasing of $A_{S}$ value for the pair "acetone - chloroform", where $\Delta \mathrm{R}_{\mathrm{f}}$ is in the range from 0.021 to 0.027 , and for "propan-2-ol acetone", where $\Delta R_{f}$ slightly decreases from 0.058 to 0.032 .

Table 4

The relative retention of $\mathbf{R}_{\mathrm{f}}$ for compounds I-VIII depending on the composition of the binary MP (benzene-polar component) for aromatic derivatives of 3-chloro-1,4-naphthoquinone

\begin{tabular}{|c|c|c|c|c|c|c|}
\hline $\begin{array}{l}\text { Substance } \\
\text { number }\end{array}$ & $\begin{array}{l}\text { The content of the } \\
\text { polar component in } \\
\text { the eluent, \% vol. }\end{array}$ & Chloroform & Propan-2-ol & Methanol & Acetone & Acetonitrile \\
\hline \multirow{4}{*}{$\mathbf{I}$} & 2.5 & 0.390 & 0.465 & 0.462 & 0.416 & 0.327 \\
\hline & 5.0 & 0.485 & 0.564 & 0.557 & 0.511 & 0.415 \\
\hline & 7.5 & 0.560 & 0.638 & 0.627 & 0.585 & 0.489 \\
\hline & 10.0 & 0.585 & 0.662 & 0.648 & 0.609 & 0.513 \\
\hline \multirow{4}{*}{ II } & 2.5 & 0.354 & 0.436 & 0.438 & 0.378 & 0.304 \\
\hline & 5.0 & 0.458 & 0.544 & 0.543 & 0.484 & 0.400 \\
\hline & 7.5 & 0.541 & 0.624 & 0.620 & 0.567 & 0.479 \\
\hline & 10.0 & 0.571 & 0.653 & 0.646 & 0.597 & 0.507 \\
\hline \multirow{4}{*}{ III } & 2.5 & 0.330 & 0.408 & 0.419 & 0.355 & 0.285 \\
\hline & 5.0 & 0.440 & 0.525 & 0.533 & 0.468 & 0.387 \\
\hline & 7.5 & 0.528 & 0.612 & 0.615 & 0.556 & 0.470 \\
\hline & 10.0 & 0.562 & 0.644 & 0.643 & 0.589 & 0.502 \\
\hline \multirow{4}{*}{ IV } & 2.5 & 0.320 & 0.397 & 0.413 & 0.347 & 0.276 \\
\hline & 5.0 & 0.433 & 0.518 & 0.530 & 0.463 & 0.381 \\
\hline & 7.5 & 0.523 & 0.606 & 0.613 & 0.552 & 0.466 \\
\hline & 10.0 & 0.558 & 0.640 & 0.643 & 0.586 & 0.500 \\
\hline \multirow{4}{*}{ V } & 2.5 & 0.292 & 0.367 & 0.390 & 0.319 & 0.256 \\
\hline & 5.0 & 0.411 & 0.496 & 0.516 & 0.441 & 0.366 \\
\hline & 7.5 & 0.507 & 0.592 & 0.606 & 0.536 & 0.456 \\
\hline & 10.0 & 0.546 & 0.630 & 0.640 & 0.576 & 0.494 \\
\hline \multirow{4}{*}{ VI } & 2.5 & 0.255 & 0.325 & 0.359 & 0.279 & 0.227 \\
\hline & 5.0 & 0.381 & 0.465 & 0.498 & 0.410 & 0.344 \\
\hline & 7.5 & 0.484 & 0.570 & 0.597 & 0.514 & 0.441 \\
\hline & 10.0 & 0.530 & 0.615 & 0.637 & 0.560 & 0.485 \\
\hline \multirow{4}{*}{ VII } & 2.5 & 0.231 & 0.303 & 0.340 & 0.252 & 0.210 \\
\hline & 5.0 & 0.360 & 0.448 & 0.486 & 0.389 & 0.330 \\
\hline & 7.5 & 0.468 & 0.558 & 0.591 & 0.498 & 0.432 \\
\hline & 10.0 & 0.518 & 0.607 & 0.634 & 0.549 & 0.479 \\
\hline \multirow{4}{*}{ VIII } & 2.5 & 0.156 & 0.211 & 0.272 & 0.179 & 0.152 \\
\hline & 5.0 & 0.288 & 0.369 & 0.443 & 0.322 & 0.280 \\
\hline & 7.5 & 0.410 & 0.500 & 0.568 & 0.447 & 0.395 \\
\hline & 10.0 & 0.475 & 0.567 & 0.625 & 0.513 & 0.457 \\
\hline
\end{tabular}


In Table 5 are shown the correlations of parameters A and B according to Soczewinski equation (3). The A constant in equation (3) corresponds to the $R_{M}$ value, if the MP consists only of a polar component, i.e. when $N_{B}=1$. Using the constant A, for this limit case by equation (4) was calculated the value of $R_{f}\left(N_{B}=1\right)$, which is given in Table 5 .

$$
\mathrm{R}_{\mathrm{f}}\left(\mathrm{N}_{\mathrm{B}}=1\right)=\frac{1}{1+10^{\mathrm{A}}} \text {. }
$$

In Fig. 3 shows examples of linear correlations between the $R_{M}$ retention parameter and the decimal logarithm of the molar fraction $\left(N_{B}\right)$ of the polar component in the MP. To demonstrate the basic regularity in these dependences, compounds $\mathbf{I V}, \mathbf{V}$,
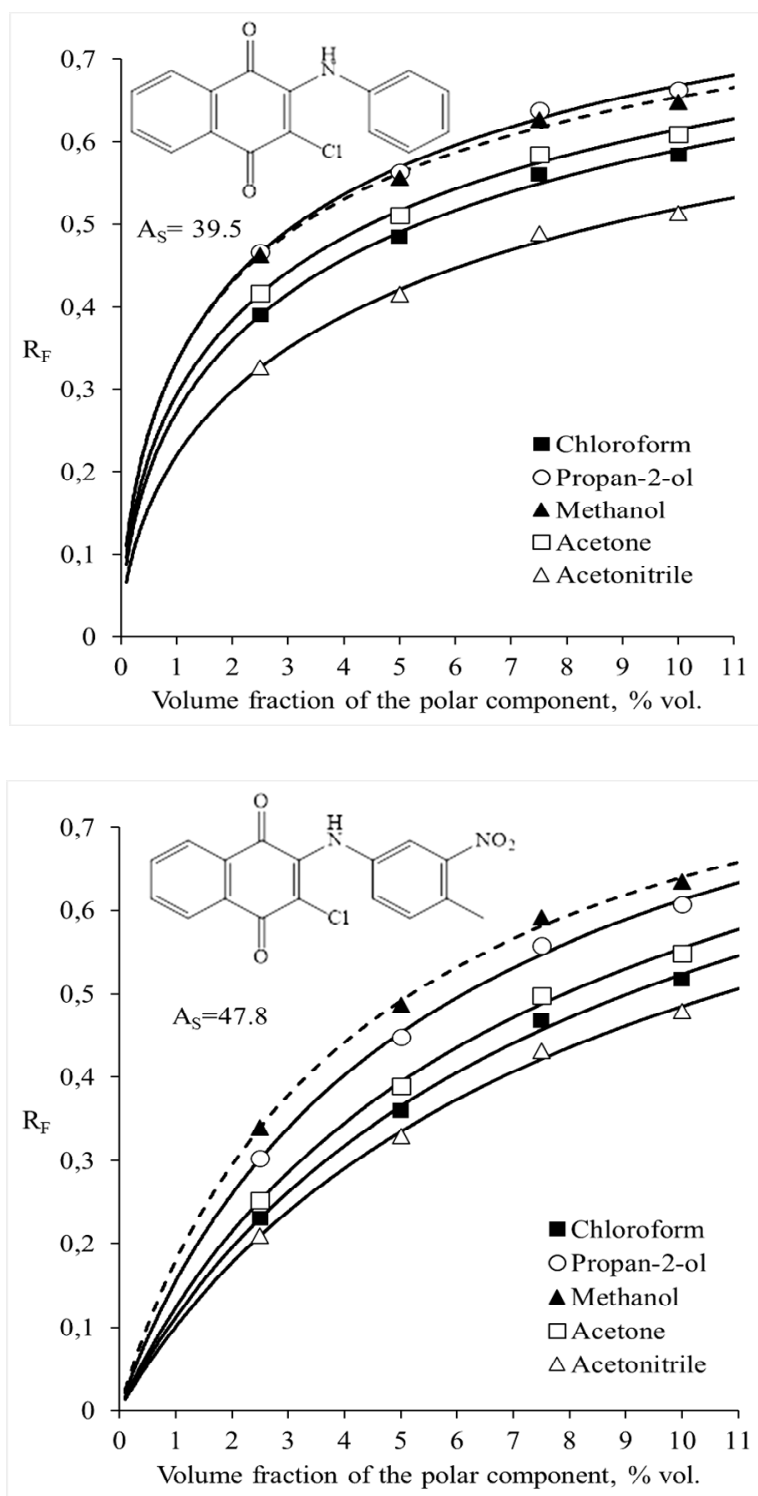

VI and VIII are taken, which differs in the calculated As values: $(\mathbf{I V})-A_{S}=40.3 ;(\mathbf{V})-A_{S}=44.1 ;(\mathbf{V I})-$ $A_{S}=47.1$ and (VIII) $-A_{S}=55.5$. With an increase in the $A_{S}$, there is an increase in slope $B$, which is in good agreement with the theory of retention in NPC, which is described in detail in the monograph [18].

The average slopes of the rectilinear dependences according to the Soczewinski equation between the retention parameter $R_{M}$ and the logarithm of the molar fraction of the polar modifier $\lg \left(N_{B}\right)$ correlate $\left(R^{2}=0.964\right)$ with the $\mathrm{A}_{\mathrm{S}}$ relative area of the analytes according to equation (5)

$$
\mathrm{B}=0.032 \cdot \mathrm{A}_{\mathrm{S}}-0.603 \text {. }
$$
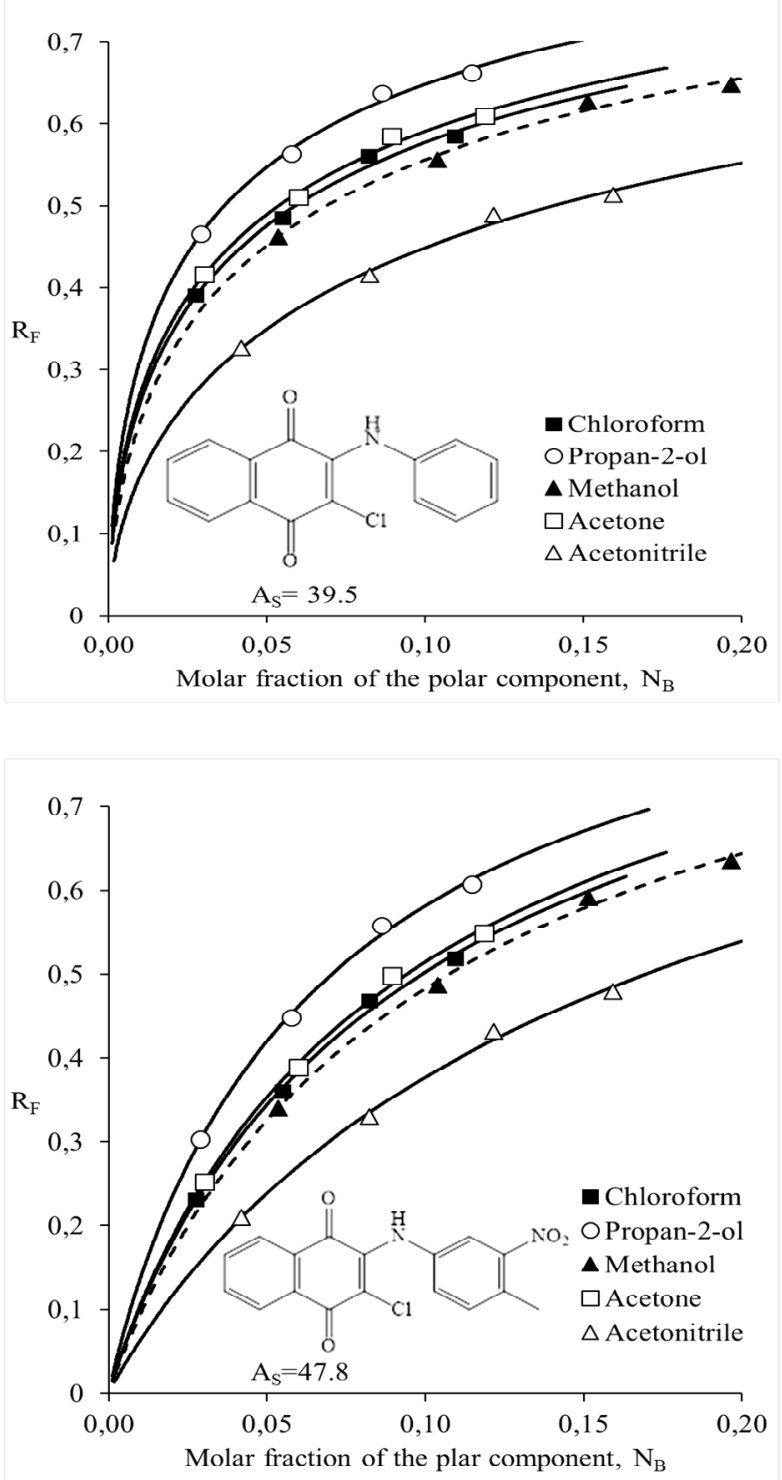

Fig. 1. Dependence between the $R_{f}$ retention parameter for compounds $\mathbf{I}$ and $\mathbf{V I I}$ on the volume (\%) and molar fraction of the polar component in the MP 
Normal phase thin layer chromatography for aromatic derivatives of 3-chloro-1,4-naphtochinone
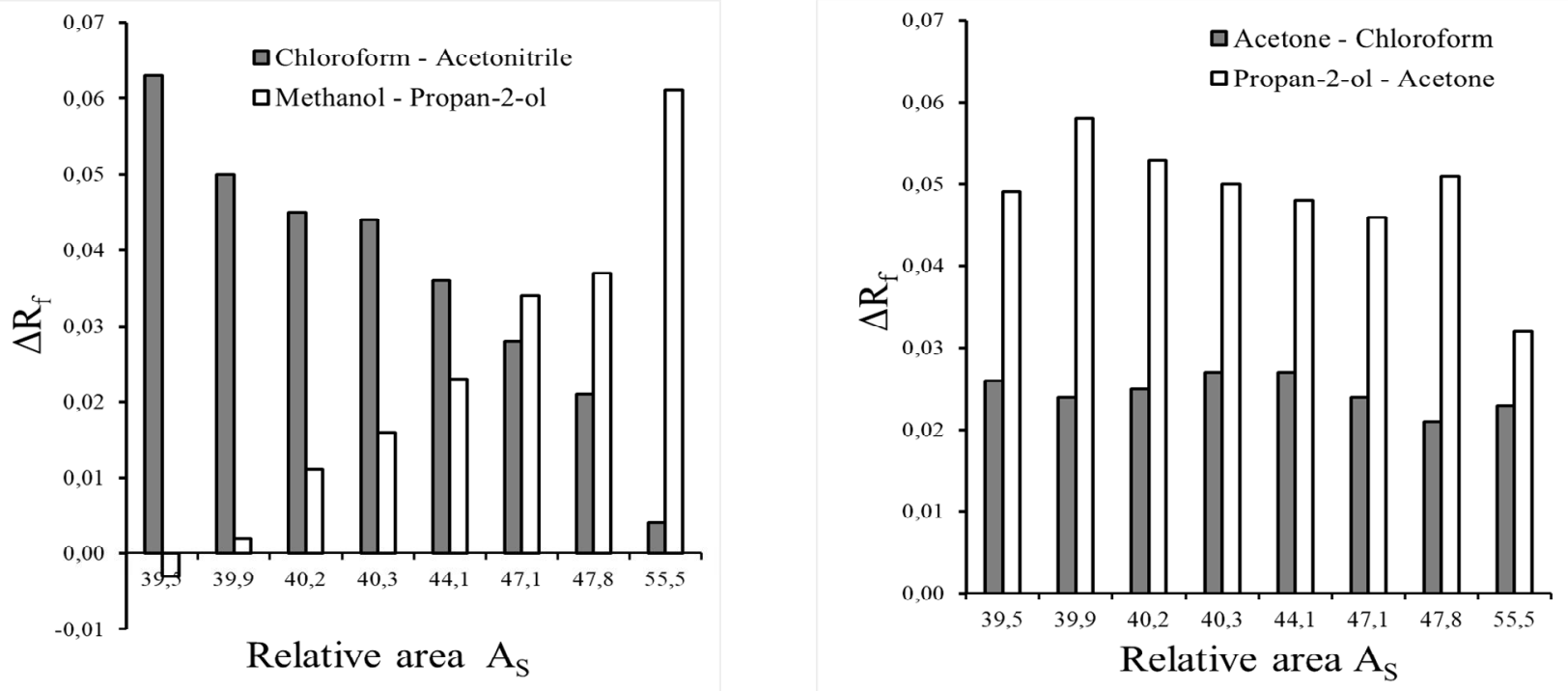

Fig. 2. The difference $\Delta R_{f}$ between adjacent polar components of $M P$ at a volume fraction of $2.5 \%$ for compounds I-VIII of the relative area $\left(A_{S}\right), \%$

Table 5

Parameters $A$ and $B$ of correlations according to the Soczewinski equation $R_{M}=A-B \cdot \lg \left(N_{B}\right)$ for the corresponding range of molar fraction of the polar component of the MP

\begin{tabular}{|c|c|c|c|c|c|c|}
\hline $\begin{array}{c}\text { Substance } \\
\text { number }\end{array}$ & $\begin{array}{l}\text { Correlation } \\
\text { parameters }\end{array}$ & $\begin{array}{c}\text { Chloroform } \\
N_{B}=0,027-0,109\end{array}$ & $\begin{array}{c}\text { Propan-2-ol } \\
\mathrm{N}_{\mathrm{B}}=0,029- \\
\quad 0,114\end{array}$ & $\begin{array}{c}\text { Methanol } \\
N_{B}=0,053-0,196\end{array}$ & $\begin{array}{c}\text { Acetone } \\
\mathrm{N}_{\mathrm{B}}=0,030- \\
0,118\end{array}$ & $\begin{array}{c}\text { Acetonitrile } \\
N_{B}=0,042- \\
0,159\end{array}$ \\
\hline 1 & 2 & 3 & 4 & 5 & 6 & 7 \\
\hline \multirow{4}{*}{ I } & A & -0.7278 & -0.8761 & -0.7028 & -0.7481 & -0.5099 \\
\hline & B & 0.5918 & 0.6098 & 0.6048 & 0.5891 & 0.5985 \\
\hline & $R^{2}$ & 0.9926 & 0.9927 & 0.9922 & 0.9924 & 0.9919 \\
\hline & $R_{f}\left(N_{B}=1\right)$ & 0.842 & 0.883 & 0.835 & 0.848 & 0.764 \\
\hline \multirow{4}{*}{ II } & A & -0.7706 & -0.9097 & -0.7455 & -0.7992 & -0.5491 \\
\hline & B & 0.6624 & 0.6650 & 0.6719 & 0.6685 & 0.6602 \\
\hline & $R^{2}$ & 0.9937 & 0.9944 & 0.9939 & 0.9939 & 0.9934 \\
\hline & $R_{f}\left(N_{B}=1\right)$ & 0.855 & 0.890 & 0.848 & 0.863 & 0.780 \\
\hline \multirow{4}{*}{ III } & A & -0.8030 & -0.9460 & -0.7768 & -0.8302 & -0.5824 \\
\hline & B & 0.7130 & 0.7210 & 0.7225 & 0.7170 & 0.7132 \\
\hline & $R^{2}$ & 0.9947 & 0.9946 & 0.9942 & 0.9945 & 0.9947 \\
\hline & $R_{f}\left(N_{B}=1\right)$ & 0.864 & 0.898 & 0.857 & 0.871 & 0.793 \\
\hline \multirow{4}{*}{ IV } & A & -0.8174 & -0.9570 & -0.7888 & -0.8406 & -0.6006 \\
\hline & B & 0.7347 & 0.7407 & 0.7404 & 0.7335 & 0.7403 \\
\hline & $R^{2}$ & 0.9948 & 0.9954 & 0.9951 & 0.9949 & 0.9952 \\
\hline & $R_{f}\left(N_{B}=1\right)$ & 0.868 & 0.901 & 0.860 & 0.874 & 0.799 \\
\hline \multirow{4}{*}{ V } & $\mathrm{A}$ & -0.8552 & -0.9968 & -0.8280 & -0.8776 & -0.6369 \\
\hline & B & 0.7957 & 0.8028 & 0.8042 & 0.7944 & 0.7991 \\
\hline & $R^{2}$ & 0.9954 & 0.9957 & 0.9956 & 0.9961 & 0.9959 \\
\hline & $R_{f}\left(N_{B}=1\right)$ & 0.878 & 0.908 & 0.871 & 0.883 & 0.813 \\
\hline
\end{tabular}


Continuation of Table 5

\begin{tabular}{|c|c|c|c|c|c|c|}
\hline 1 & 2 & 3 & 4 & 5 & 6 & 7 \\
\hline \multirow{4}{*}{ VI } & $\mathrm{A}$ & -0.9112 & -1.0519 & -0.8868 & -0.9355 & -0.6944 \\
\cline { 2 - 7 } & $\mathrm{B}$ & 0.8836 & 0.8911 & 0.8957 & 0.8869 & 0.8908 \\
\cline { 2 - 7 } & $R^{2}$ & 0.9965 & 0.9966 & 0.9965 & 0.9966 & 0.9967 \\
\cline { 2 - 7 } & $R_{f}\left(N_{B}=1\right)$ & 0.891 & 0.918 & 0.885 & 0.896 & 0.832 \\
\hline \multirow{4}{*}{ VII } & $\mathrm{A}$ & -0.9482 & -1.0838 & -0.9204 & -0.9796 & -0.7303 \\
\cline { 2 - 7 } & $\mathrm{B}$ & 0.9438 & 0.9407 & 0.9506 & 0.9551 & 0.9484 \\
\cline { 2 - 7 } & $R^{2}$ & 0.9968 & 0.9970 & 0.9967 & 0.9972 & 0.9967 \\
\cline { 2 - 7 } & $R_{f}\left(N_{B}=1\right)$ & 0.899 & 0.924 & 0.893 & 0.905 & 0.843 \\
\hline \multirow{4}{*}{ VIII } & $\mathrm{A}$ & -1.0924 & -1.2309 & -1.0573 & -1.1129 & -0.8736 \\
\cline { 2 - 7 } & $\mathrm{B}$ & 1.1717 & 1.1739 & 1.1675 & 1.1674 & 1.1763 \\
\cline { 2 - 7 } & $R^{2}$ & 0.9978 & 0.9981 & 0.9979 & 0.9981 & 0.9981 \\
\cline { 2 - 7 } & $R_{f}\left(N_{B}=1\right)$ & 0.925 & 0.945 & 0.919 & 0.928 & 0.882 \\
\hline
\end{tabular}

Two-parameter linear correlations between the mean slopes in Soczewinski equation (3) with the $A_{S}$ area of analytes were also obtained in previous works [14-16].

The summary of the intercept $(\boldsymbol{p})$ and slope $(\boldsymbol{q})$ parameters of these correlations, which is given in Table 6, shows a satisfactory similarity of these values for different sets of analytes. The correlation dependence $\boldsymbol{B}=\boldsymbol{q} \boldsymbol{+} \boldsymbol{p} \cdot \boldsymbol{A}_{S}$ can be used to estimate the slope in the Soczewinski equation, using the calculated relative area $A_{S}$ of the analyte.

Table 6

Parameters of linear correlations $B=q+p \cdot A_{S}$

\begin{tabular}{|l|c|c|c|}
\hline $\begin{array}{c}\text { Literature, number } \\
\text { of analysts }\end{array}$ & $p$ & $\mathrm{q}$ & $R^{2}$ \\
\hline$[18], n=7$ & 0.0323 & -0.623 & 0.987 \\
\hline$[19], \mathrm{n}=7$ & 0.0272 & -0.313 & 0.988 \\
\hline$[20], n=6$ & 0.0282 & -0.421 & 0.985 \\
\hline This work, $n=8$ & 0.0320 & -0.603 & 0.964 \\
\hline
\end{tabular}

For an MP with a certain polar component, the existence of linear correlations between intercepts (A) and slopes (B) in the Soczewinski equation was revealed. For different polar components of the MP straight lines have close slopes $(\boldsymbol{k})$ and different intercepts $(\boldsymbol{m})$, that are given in Table 7 .

The largest absolute value of the intercept 0.7803 among these straight lines was obtained for propan-2-ol, and for the other polar components of the mobile phase, this value is in the range of 0.210.60. At the comparison of Fig. 1 in the coordinates of the molar fraction and intercepts of Table 7 in the series of increasing $R_{f}$ value and increasing of the absolute values of the intercepts in the linear relationships between parameters $\mathrm{A}$ and $\mathrm{B}$, the same sequence is observed: acetonitrile-methanolchloroform-acetone-propan-2-ol. The values of $\boldsymbol{k}$ and $\boldsymbol{m}$ parameters for the dependences between the $\mathrm{A}$ and $B$ values, obtained for the studied series of compounds I-VIII with the phenylamine fragment in the second position of 1,4-naphthoquinone, were compared with the results of studies $[14,15]$. The relationship between the values of $\boldsymbol{m}$ and $\boldsymbol{k}$ for a certain polar component in the MP and three different sets of substances and are described in Fig. 4 as linear dependencies.

Table 7

\section{Parameters of linear correlations $B=m+k \cdot A$ between the values of $A$ and $B$ from the Soczewinski equation}

\begin{tabular}{|l|c|c|}
\hline $\begin{array}{c}\text { The polar component } \\
\text { of the MP }\end{array}$ & $k$ & $m$ \\
\hline Acetonitrile & -1.5902 & -0.2133 \\
\hline Methanol & -1.5880 & -0.5115 \\
\hline Chloroform & -1.5879 & -0.5626 \\
\hline Acetone & -1.5888 & -0.6008 \\
\hline Propan-2-ol & -1.5881 & -0.7803 \\
\hline
\end{tabular}


Normal phase thin layer chromatography for aromatic derivatives of 3-chloro-1,4-naphtochinone
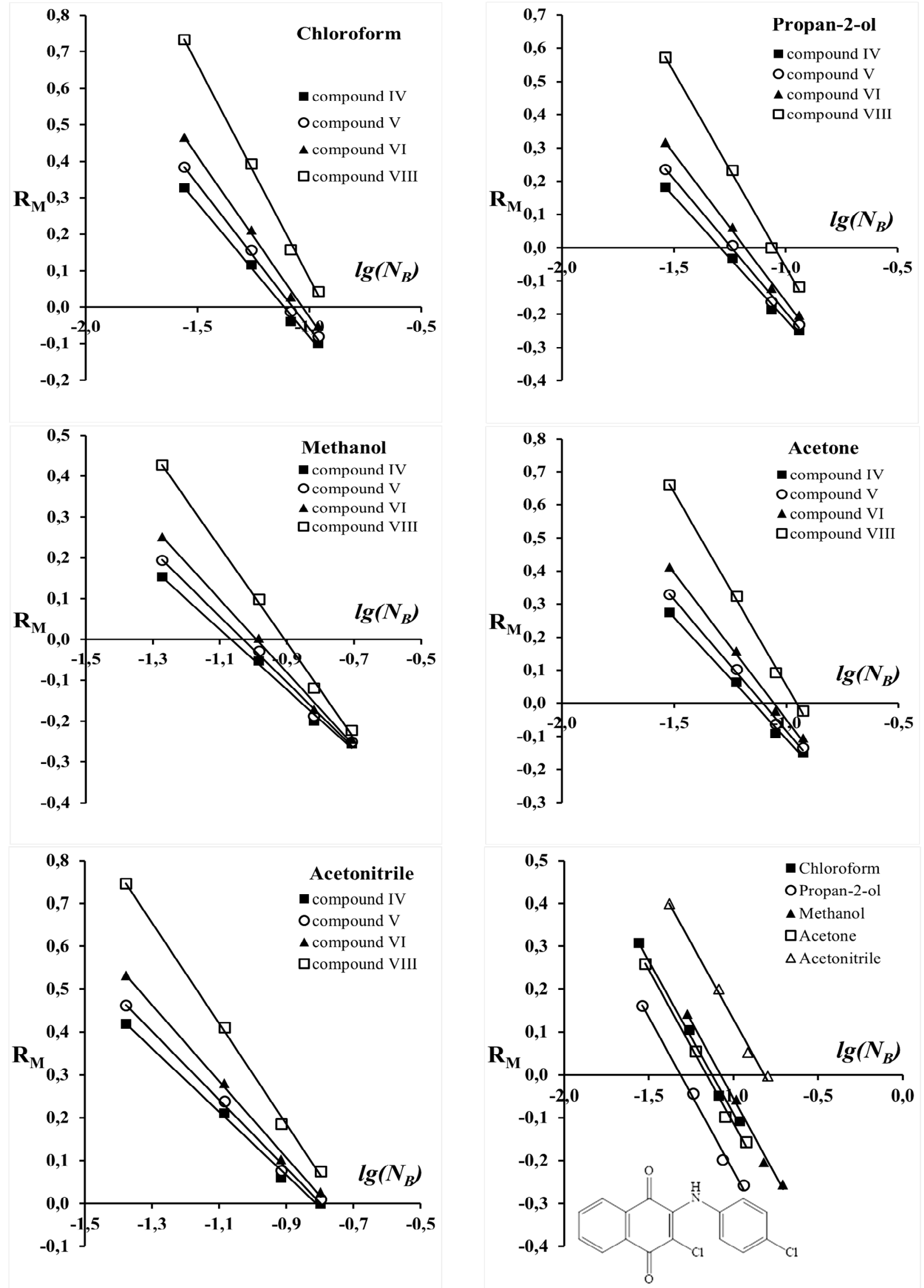

Fig. 3. The relationship between the $R_{M}$ retention parameter for compounds $\boldsymbol{I V}, \boldsymbol{V}, \boldsymbol{V I}$ and $\boldsymbol{V I I I}$ and the decimal logarithm of the molar fraction $\left(N_{B}\right)$ of the polar component in the MP 


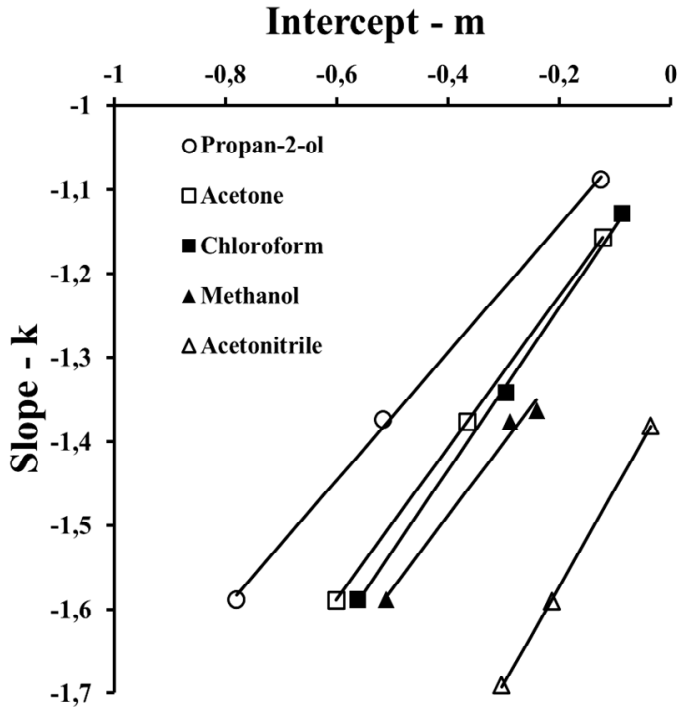

Fig. 4. Relationship between correlation parameters $B=m+k \cdot A$ according to this study and works $[14,15]$

For different sets of compounds, the values of $\boldsymbol{m}$ and $\boldsymbol{k}$ for a certain polar component in the MP differs, but the overall sequence of changes in the $\boldsymbol{m}$ and $\boldsymbol{k}$ values remains unchanged in the serie: acetonitrile - methanol - chloroform - acetone propan-2-ol. The obtained correlation dependences can be used to predict the retention under NP TLC for 1,4-naphthoquinone derivatives by their structure.

\section{Conclusions}

The retention of eight aromatic derivatives of 3-chloro-1,4-naphthoquinone, compounds I-VIII in the conditions of normal phase TLC with silica gel as SP, and binary MP based on benzene with a volume fraction of the corresponding polar components in the range of $2.5-10 \%$ vol. At the use of the volume fraction (\%) as the coordinates of the abscissa axis, an increase in the value of $R_{f}$ was found for all compounds I-VIII ar the replacement of the mobile phase polar component in the following series: acetonitrile - chloroform acetone - propan-2-ol - methanol.

The largest difference in the values of $R_{f}$ between the studied substances was observed for all used polar components of MP at a concentration of $2.5 \%$, i.e. the maximum separation of the studied compounds I-VIII by TLC is achieved. With the increase of the polar component content in the MP, there is a decrease in this difference and at $10.0 \%$ vol. all analytes have almost the same values of $R_{f}$.

\section{References}

1. Bechtold T. (2010). Handbook of natural colorants. Chichester: Wiley.

2. Ibis Cemil, Tuyun Amac Fatih, Bahar Hakan, Ayla Sibel Sahinler, Stasevych Maryna V., Musyanovych Rostyslav ... Novikov Volodymyr (2013). Synthesis of novel 1,4-naphthoquinone derivatives: antibacterial and antifungal agents. Medicinal Chemistry Research, 22(6), 2879-2888. doi:10.1007/s00044-012-0300-y

3. Deniz, Nahide Gülşah; Ibis, Cemil; Gokmen, Zeliha; Stasevych, Maryna; Novikov, Volodymyr; ... Ozyurek, Mustafa; Guclu, Kubilay; Karakas, Didem; Ulukaya, Engin (2015). Design, Synthesis, Biological Evaluation, and Antioxidant and Cytotoxic Activity of Heteroatom-Substituted 1,4-Naphtho- and Benzoquinones. Chemical and Pharmaceutical Bulletin, 63(12), 10291039. doi:10.1248/cpb.c15-00607

4. Sieveking, Ivan; Thomas, Pablo; Estévez, Juan C.; Quiñones, Natalia; Cuéllar, Mauricio A.; Villena, Juan; Espinosa-Bustos, Christian; Fierro, Angélica; Tapia, Ricardo A.; Maya, Juan D.; López-Muñoz, Rodrigo; Cassels, Bruce K.; Estévez, Ramon J.; Salas, Cristian O. (2014). 2-Phenylaminonaphthoquinones and related compounds: Synthesis, trypanocidal and cytotoxic activities. Bioorganic \& Medicinal Chemistry, 22(17), 4609-4620. doi:10.1016/j.bmc.2014.07.030

5. Prachayasittikul, V., Pingaew, R., Worachartcheewan, A., Ruchirawat, S., \& Prachayasittikul, V. (2014). Synthesis, anticancer activity and QSAR study of 1,4-naphthoquinone derivatives. European Journal of Medicinal Chemistry, 84, 247-263. doi:10.1016/j.ejmech.2014.07.024

6. Ibis, C., Shntaif, H., Bahar, H., \& Ayla, S. (2015). An investigation of nucleophilic substitution reactions of 2,3-dichloro-1,4-naphthoquinone with various nucleophilic reagents. Journal of the Serbian Chemical Society, 80(6), 731-738. doi:10.2298/jsc141124021i

7. Shakh, Y. U., Romanenko, I., Slesarchuk, M., Syngaevsky, V., Kovalchuk, O., Bolibrukh, K., Karkhut, A., ... O., Polovkovych, S. \& Novikov, V. (2017). Synthesis and Antimicrobial Activity of 1,4-Naphthoquinones Derivatives with [1,2,4]-Triazole-3-thione Substitution. Indian Journal of Pharmaceutical Sciences, 79(4), 650654. doi:10.4172/pharmaceutical-sciences. 1000275

8. Tandon, V. K., Singh, R. V., \& Yadav, D. B. (2004). Synthesis and evaluation of novel 1,4naphthoquinone derivatives as antiviral, antifungal and anticancer agents. Bioorganic \& Medicinal Chemistry Letters, 14(11), 2901-2904. doi:10.1016/j.bmcl.2004.03.047

9. Phillips, R. M., Jaffar, M., Maitland, D. J., Loadman, P. M., ..., Patterson, A.V. \& Stratford, I. J. 
(2004). Pharmacological and biological evaluation of a series of substituted 1,4-naphthoquinone bioreductive drugs. Biochemical Pharmacology, 68(11), 2107-2116. doi:10.1016/j.bcp.2004.08.007

10. Mathew, N., Karunan, T., Srinivasan, L., \& Muthuswamy, K. (2010). Synthesis and screening of substituted 1,4-naphthoquinones (NPQs) as antifilarial agents. Drug Development Research, 71, 188-196. doi:10.1002/ddr.20357

11. Kurban, S., Deniz, N. G., Sayil, C., Ozyurek, M., Guclu, K., Stasevych, M., Zvarych, V., KomarovskaPorokhnyavets, O. \& Novikov, V. (2019). Synthesis, Antimicrobial Properties, and Inhibition of Catalase Activity of 1,4-Naphtho- and Benzoquinone Derivatives Containing N-, S-, O-Substituted. Heteroatom Chemistry, 2019, 1-12. doi:10.1155/2019/1658417

12. Yildirim, H. (2017). Synthesis and Structural Analysis of Some New Sulfanyl Amino 1,4-Naphthoquinone Derivatives. Journal of the Turkish Chemical Society, Section A: Chemistry, 5(1), 149-158. doi: 10.18596/ jotcsa.335894

13. Kotakemori, M., \& Okada, K. (1966). Thinlayer Chromatography of Some Substituted Naphthoquinones. Agricultural and Biological Chemistry, 30(9), 935-936. doi: $10.1271 / \mathrm{bbb} 1961.30 .935$

14. Smirnova O. Ya., Polyuzhyn I. P., Yatchyshyn Yo. Yo. (2018). Normalnofazova tonkosharova khromatografiya dlya cyklichnyh pokhidnyh 3hloro-1,4-naftohinonu. Visnyk Nacionalnogo universytetu "Lvivska politehnika". Himiya, texnologiya rechovyn ta yih zastosuvannya, 886, 14-22.
15. Smirnova O. Ya., Poliuzhyn I. P., Yatchyshyn Yo. Yo. (2018). Zalezhnosti mizh strukturoiu aminokyslotnykh pokhidnykh 3-khlor-1,4-naftokhinonu ta yikh utrymuvanniam $\mathrm{v}$ umovakh priamofazovoi tonkosharovoi khromatohrafii. Pytannia khimii ta khimichnoi tekhnolohii, 4 (119), S. 59-68. Retrieved from: http://udhtu.edu.ua/public/userfiles/file/VHHT/2018/4/Sm irnova.pdf

16. Poliuzhyn Ihor, Smirnova Oksana, Yatchyshyn Yosyp (2018). Thin Layer Chromatography for Some Derivatives of 1,4-Naphthoquinone. - 8-th International Joint Youth Science Forum "Litteris et Artibus" (November, 22-24, 2018) / Proceedings. Lviv: "Lviv Polytechnic Press" (1 CD-ROM). P. 162-167.

17. Snyder L. R. (1968). Principles of adsorption chromatography. New York: Dekker

18. Snyder L. R., Kirkland J. J., Dolan J. W. (2010). Introduction to Modern Liquid Chromatography. John Wiley \& Sons, Inc.

19. Shandrenko, S. H., Holovin, A. S., Dmytrenko, M. P., Yurchenko, A. I., Babycheva, O. F. (2002). Kompiuterna reiestratsiia ta analiz rezultativ tonkosharovoi khromatohrafii. Zhurnal Khromatohrafichnoho tovarystva, 2(4), 22-30. doi: 10.15407/zht.2002.2.4.22

20. Snyder, L. R. (1974). Classification of the solvent properties of common liquids. Journal of Chromatography A, 92(2), 223-230. doi:10.1016/s00219673(00)85732-5

21. Snyder, L. R., Carr, P. W., \& Rutan, S. C. (1993). Solvatochromically based solvent-selectivity triangle. Journal of Chromatography A, 656 (1-2), 537-547. doi:10.1016/0021-9673(93)80818-s

О. Я. Смірнова, Й. Й. Ятчишин, С. В. Колобич, І. П. Полюжин

Національний університет “Львівська політехніка", кафедра фізичної, аналітичної та загальної хімії ihor.p.poliuzhyn@lpnu.ua

\section{НОРМАЛЬНОФАЗОВА ТОНКОШАРОВА ХРОМАТОГРАФІЯ ДЛЯ АРОМАТИЧНИХ ПОХІДНИХ 3-ХЛОРО-1,4-НАФТОХІНОНУ}

Досліджено хроматографічні характеристики восьми ароматичних похідних 3-хлоро-1,4нафтохінону в умовах нормальнофазової тонкошарової хроматографії для бінарної мобільної фази на основі бензолу і таких полярних розчинників, як хлороформ, ацетон, ацетонітрил, метанол i пропан-2-ол. Нахил лінійних залежностей утримування досліджених сполук від концентрації полярного компонента в мобільній фазі задовільно корелюс із площею, яку займас адсорбована молекула аналіту на нерухомій фазі. Відтинок у рівнянні Сочевінського залежить від полярного компонента мобільної фази.

Ключові слова: тонкошарова хроматографія; нафтохінон-1,4; ароматичні похідні; склад елюента; рівняння Сочевінського. 